\title{
TWO OR MORE DAEMON-ANIMALS
}

\author{
I Haunt Myself
}

Goat-Gog loves mint: my grandma's child-ghost who

pees on boys from trees; low swooping

Crow-Ma-Gog nervous from his breakfast-ghosts' blue

rage; the blanket flowers under his

feet; love notes I float down the creek; fizz

flowing over cups. It's Monday morning. Walking

over old perceptions of marshland,

fields (there is no organ for memory, only perceiving,

past, present, future all at once) -

I haunt myself, the corn where I grew up, chance

death by astral travel, whisper threats into my mother's boyfriends' ears. Goat-Gog, flinging

horns across them, drags their souls (bullet-ed tin cans) through The Undertow. The lightning

sounds always after in their coiled heads.

Goat-Gog eats persimmons, chews my braids, lounges

like a king upon my bed, says, Someday

I'll be explained by science - scrounging

for a vanished fruit. Crow-Ma-Gog multiplies

herself until the room's a riot, flies

\section{Who Am I?}

feathers in my face, sings, One one, one one, till we want to choke her. Now my soul is two, Goat-Gog and Crow-Ma-Gog, who am I?

Owl-Gog? Then who am I? Car-Gog?

Still, who am I? I? And so on. 
Pages spread across the floor-Cain-Gog? Shadows pull each other's edges, forming wings. His inward breathing rasps like static. Wires grow from his mouth and ears. My feet catch fire. They burn for weeks.

Who claimed that dark is light's absence? Night spools monochrome threads through our chests and eyes. So Cain-Gog creeps, destroys. I was a fool to make him up. Collective Unconscious, spin him in the Hadron Collider. Hear us!

Modern man, Goat-Gog whines, is hyperconscious, self sees self seeing self... Coaxing

my grandma's child-ghost, Betty, from the ceiling, I rock her one one, one one, through the night's

fluid rush of planets, her bright

seraph-wrists around my neck.

We're Back in the Field

Why, I ask them,

do I imagine us in the same blue bedroom? Washer and dryer tucked behind the closet door, trumpeting wallpaper angels, rock albums strewn across the floor, black

fishnets drying on a chair? Crow-Ma-Gog's nervous preening halts and starts. She doesn't like it here-the blue room wavers, seethes, and disappears. We're back in the field. April is the cruelest month, Goat-Gog squeals 
like a lunatic. I crash into my grandpa,

Ron, as he flashes a row of little girls, creeps into my mother's room, and lifts her shirt. I choose

not to be one with him. I refuse

and wake in the heat of my childhood bed.

Borges's celestial library exists

beyond the dryer. Notice: Moth-Gog perished reading

Donne's Death's Duel. Let's leave her

until she's dust. I pull my covers

through the portal, sleep snailed inside the shelf. Dear, dear, I say, to no one, to everyone.

Crow-Gog sticks her beak inside my ear, chews memories of that crazed evangelist;

her witch's hands cold on my chest;

Where Is the Child I Was?

the burnt notebook; witches I named and loved;

the muse whose name I signed

on every page. Where is the brave child I was?

Clouds and tiny purple flowers

crush me now. The dryer

opens and I drop-fractured planets

spin around me, suns dim to amulets.

I wear the severed heads of horses, bulls, humans, buffalo. Goat and Crow burn away, then all beings too buried to name. 